\title{
Angio-oedema in relation to treatment with angiotensin converting enzyme inhibitors
}

\author{
Thomas Hedner, Ola Samuelsson, Helen Lunde, Lars Lindholm, Lennart Andrén, \\ Bengt-Erik Wiholm
}

\begin{abstract}
Objective-To evaluate and describe the clinical course of angio-oedema reactions induced by angiotensin converting enzyme inhibitors.

Design and methods - All reports of angio-oedema reactions associated with angiotensin converting enzyme inhibitors submitted to Swedish Adverse Reactions Advisory Committee were reviewed and the clinical courses summarised. Numbers of cases judged to be induced by angiotensin converting enzyme inhibitors were related to their annual usage, estimated from total sales of defined daily doses, as well as to the estimated number of new patients. All cases of angio-oedema associated with angiotensin converting enzyme inhibitors reported to the World Health Organisation's international drug information system were also summarised.
\end{abstract}

Results -36 of the 38 reported cases in Sweden between 1981 and 1990 were judged to be related to angiotensin converting enzyme inhibitors. During 1981 through 1990, altogether 1309 cases of angiooedema associated with angiotensin converting enzyme inhibitors were registered with the international drug information system. The incidence of reported cases of angio-oedema increased largely in parallel with the increased sales (usage) of angiotensin converting enzyme inhibitors. Of the 36 Swedish patients, $77 \%$ experienced the reaction within the first three weeks after starting treatment. 10 patients needed hospitalisation, two of whom had life threatening laryngeal obstruction. With one exception all 36 patients were free of symptoms within one week after discontinuing the drug.

Conclusions-Angio-oedema induced by angiotensin converting enzyme inhibitors is a rare but potentially life threatening reaction, which in most instances occurs shortly after the start of treatment. Any patient in whom the reaction is suspected should have the treatment interrupted and, if necessary, be admitted for observation.

\section{Introduction}

Angio-oedema is a local, well defined, non-pitting erythematous oedema involving the skin and subcutaneous tissue. 'The most common location is the face, involving eyelids, lips, and the tongue, but it can also occur at other sites, such as the back of the hands and feet and genitalia. Mucous membranes may also be involved..$^{2}$ In contrast with the rare hereditary form, ${ }^{3}$ isolated non-hereditary cases precipitated by trauma, temperature, food, or food additives may occur in up to $10 \%$ of the population. ${ }^{4}$ This idiopathic sporadic form of angio-oedema is usually milder than the hereditary form. A variety of agents may precipitate the reaction.

Angio-oedema has recently been reported in association with angiotensin coverting enzyme inhibitor treatment. ${ }^{6-10}$ These reports of angio-oedema include structurally different angiotensin converting enzyme inhibitors, indicating that this particular adverse reaction may be related to the pharmacological actions of this whole class of drugs. The incidence of angiotensin converting enzyme inhibitor related angiooedema has been reported to be about $0 \cdot 1 \%$ to $0 \cdot 2 \%{ }^{8}$

In order to evaluate angiotensin converting enzyme inhibitor associated angio-oedema we have summarised all the reports of this particular adverse reaction that have been submitted to the Swedish Adverse Drug Reactions Advisory Committee ${ }^{11}$ up to the end of 1990, describing the onset of symptoms, the duration of treatment before the reaction, the clinical course, and the possible associations with concomitant diseases. We have also summarised the number of reports of angiotensin converting enzyme inhibitor associated angio-oedema submitted to the World Health Organisation's database of individual case reports on adverse drug reactions. ${ }^{12}$

\section{Patients and methods}

In Sweden all new or serious adverse reactions suspected to be related to treatment with a pharmacological agent must be reported to the Swedish Adverse Drug Reactions Advisory Committee. All such reports are scrutinised by a panel of experts, who decide whether the reported reaction could be classified as a drug induced adverse effect. All cases of angiooedema which occurred after the initiation of angiotensin converting enzyme inhibitor therapy reported during 1981 through 1990 were reviewed. The definition of possible angiotensin converting enzyme inhibitor induced angio-oedema was the occurrence of any oedema or swelling involving the chin, neck, eyes, face, lips, mouth, tongue, throat, or larynx after such treatment had been initiated, provided that any other possible triggering event or pathogenetic factor for urticaria or Quincke's oedema was absent.

The numbers of reported cases were related to the annual use of the angiotensin converting enzyme inhibitors captopril, enalapril, and lisinopril. Captopril was registered in 1982, enalapril in 1985, and lisinopril and ramipril in 1989. Cilazapril, benazepril, and quinapril were registered during 1990. The cases reported before the dates of registration occurred during clinical trials. The total sales of drugs from all pharmacies have been computerised since 1972, and the annual usage of the drugs can be expressed in defined daily doses. Defined daily dose is an estimated average dose for an adult when the drug is used for its main indication, in this case hypertension. The defined daily dose for captopril was initially $150 \mathrm{mg}$ but was lowered to $50 \mathrm{mg}$ in 1988 . The defined daily dose for enalapril was $20 \mathrm{mg}$, for lisinopril $20 \mathrm{mg}$, and for ramipril $5 \mathrm{mg}$. 
The numbers of reports of adverse drug reactions related to angiotensin converting enzyme inhibitors in the period 1980-90 in the WHO's international drug information system ${ }^{12}$ were also summarised. This register covers 33 countries. From the start, in 1968 , 10 countries participated in the system (Australia, Canada, Czechoslovakia, Federal Republic of Germany, Ireland, the Netherlands, New Zealand, Sweden, United Kingdom, and United States). During 1969-77, 13 countries joined (Belgium, Bulgaria, Denmark, Finland, France, Indonesia, Israel, Italy, Japan, Norway, Poland, Romania, and Yugoslavia). Finally, 11 countries joined during 1978-91 (Malaysia, Iceland, Greece, Hungary, Spain, Turkey, East Germany, Thailand, Costa Rica, Austria, and Switzerland). East Germany was later withdrawn. In December 1990, reports of angiotensin converting enzyme inhibitor related angio-oedema were available from 15 countries for captopril, from 15 countries for enalapril, and from six countries for lisinopril. In the WHO's international drug information system register the number of reports on each drug is available by country. However, any comparisons of drug specific incidence of angio-oedema cannot be made since there is no available information on the number of patients starting therapy with the specific drugs each year.

The information in the international drug information system register at the WHO Collaborating Centre for International Drug Monitoring (Uppsala, Sweden) is not homogeneous, at least with respect to origin or likelihood that the pharmaceutical product caused the adverse reaction.
The information in this paper does not represent the opinion of the WHO.

\section{Results}

During 1981-90 a total of 38 cases of suspected angiotensin converting enzyme inhibitor induced angio-oedema were reported to the Swedish Adverse Drug Reactions Advisory Committee. Thirty six cases were judged to be related to angiotensin converting enzyme inhibitor treatment. These cases are summarised in table I. Three cases were reported with captopril treatment in 1981, 1986, and 1990. The first case related to captopril treatment had received a high daily dose of $450 \mathrm{mg}$. Between 1984 and 1990 a total of 27 cases were reported with enalapril, and during 198990 there were six cases with lisinopril. The prescriptions of ramipril, cilazapril, benazepril, and quinapril were very low until the end of 1990 , and no case of angiooedema related to these substances was reported in Sweden during the survey. Figure 1 shows the annual number of reported cases in relation to the annual sales of angiotensin converting enzyme inhibitors defined as the number of prescribed defined daily doses. Certainly, the experience in Sweden illustrates that during the past five years the incidence of reported cases of angio-oedema increased largely in parallel with the increased prescription of angiotensin converting enzyme inhibitors.

In 30 of the 36 cases the available clinical report included the exact time when the symptoms first occurred in relation to the first dose taken of the

TABLE I - Details of 36 cases of angio-oedema judged to be related to treatment with angiotensin converting enzyme inhibitors

\begin{tabular}{|c|c|c|c|c|c|c|c|c|}
\hline Case & Sex & Age (years) & Time on therapy & Localisation & Other treatment & Concomitant disease & $\begin{array}{c}\text { Angiotensin } \\
\text { converting enzyme } \\
\text { inhibitor }\end{array}$ & Dose \\
\hline 1 & $M$ & 72 & 3 weeks & Face, lips & $\mathrm{BB}, \mathrm{D}$ & None & Enalapril & $20 \mathrm{mg}$ \\
\hline 2 & $M$ & 45 & $1-2$ days & Face, hands, feet & $\mathrm{BB}, \mathrm{ASA}, \mathrm{N}, \beta_{2}$ stim & Asthma & Enalapril & $10 \mathrm{mg}$ \\
\hline 3 & $\mathrm{~F}$ & 59 & $2-3$ days & Lips, tongue & D & Allergic rhinitis & Enalapril & $5 \mathrm{mg}$ \\
\hline 4 & $M$ & 55 & 2 weeks & Face & $\mathrm{D}$ & None & Enalapril & $20 \mathrm{mg}$ \\
\hline 5 & $\mathrm{~F}$ & 58 & 7 days & Face, lips & None & $\begin{array}{l}\text { Diabetes mellitus, } \\
\text { asthma }\end{array}$ & Enalapril & $10 \mathrm{mg}$ \\
\hline 6 & $M$ & 44 & 5 days & Lips & None & $\begin{array}{l}\text { Diabetes mellitus, } \\
\text { alcohol abuse }\end{array}$ & Enalapril & $10 \mathrm{mg}$ \\
\hline 7 & F & 59 & 1 day & Face, arms, legs & $\mathrm{BB}$, tranquillisers & None & Enalapril & $5 \mathrm{mg}$ \\
\hline 8 & $\mathbf{F}$ & 45 & 4 days & Pharynx & $\mathrm{BB}, \mathrm{D}$ & None & Enalapril & $5 \mathrm{mg}$ \\
\hline 9 & $M$ & 61 & 3 weeks & Lips, scrotum, feet & D & None & Enalapril & $20 \mathrm{mg}$ \\
\hline 10 & $M$ & 53 & 1 day & Tongue, pharynx & $\beta_{2}$ stim, Theo & $\begin{array}{l}\text { Bronchitis, renal } \\
\text { insufficiency }\end{array}$ & Enalapril & $5 \mathrm{mg}$ \\
\hline 11 & $\mathrm{~F}$ & 61 & $<8$ weeks & Face, legs & None & None & Enalapril & $20 \mathrm{mg}$ \\
\hline 12 & $M$ & 80 & 1 day & Tongue, larynx & $\mathrm{BB}$, estramustine & Prostatic malignancy & Enalapril & $10 \mathrm{mg}$ \\
\hline 13 & $\mathrm{~F}$ & 26 & 8 days & Pharynx/larynx & $\mathrm{D}$ & Suspected SLE & Captopril & $50 \mathrm{mg}$ \\
\hline 14 & $\mathrm{~F}$ & 74 & $\mathrm{NR}$ & Tongue, mouth, face & Cort, chlorambucil & Rheumatoid arthritis & Enalapril & $5 \mathrm{mg}$ \\
\hline 15 & $M$ & 64 & 6 days & Face, lips & Cort, $\beta_{2}$ stim, $D$, Dig & Bronchitis & Enalapril & $20 \mathrm{mg}$ \\
\hline 16 & $\mathrm{M}$ & 48 & $<8$ weeks & Lips, scrotum & $\mathrm{BB}, \mathrm{D}$ & Renal insufficiency & Enalapril & $5 \mathrm{mg}$ \\
\hline 17 & $\mathrm{~F}$ & 49 & 2 days & Face, lips & $\mathrm{D}$ & None & Enalapril & $10 \mathrm{mg}$ \\
\hline 18 & $\mathrm{~F}$ & 64 & 7 days & Face & D, Dig & None & Enalapril & $20 \mathrm{mg}$ \\
\hline 19 & $M$ & 67 & 3 years & Tongue, larynx & D, Dig, warfarin & MI, stroke & Enalapril & $20 \mathrm{mg}$ \\
\hline 20 & $\mathrm{~F}$ & 76 & 3 days & Face, lips & $\mathrm{D}, \beta_{2}$ stim, Theo & Asthma & Enalapril & $2.5 \mathrm{mg}$ \\
\hline 21 & $M$ & 59 & $<12$ months & Tongue, larynx & $\mathrm{BB}, \mathrm{D}$ & None & Enalapril & $5 \mathrm{mg}$ \\
\hline 22 & $\mathrm{~F}$ & 54 & 4 weeks & Face, arms & $\mathrm{BB}, \mathrm{D}$ & Diabetes mellitus & Captopril & $450 \mathrm{mg}$ \\
\hline 23 & $M$ & 36 & $<8$ weeks & $\begin{array}{l}\text { Lips, tongue, } \\
\text { pharynx }\end{array}$ & D & None & Captopril & $50 \mathrm{mg}$ \\
\hline 24 & $M$ & 82 & 9 days & Lips, tongue, larynx & ASA & None & Lisinopril & $20 \mathrm{mg}$ \\
\hline 25 & $M$ & 29 & 3 months & $\mathrm{NR}$ & NR & NR & Enalapril & $10 \mathrm{mg}$ \\
\hline 26 & $M$ & 61 & 2 weeks & Face & $\mathrm{BB}, \mathrm{D}$, potassium & Angina pectoris & Lisinopril & $5 \mathrm{mg}$ \\
\hline 27 & $\mathrm{~F}$ & 55 & 3 months & Lips & $\mathrm{BB}$ & Asthma & Enalapril & $20 \mathrm{mg}$ \\
\hline 28 & $\mathbf{F}$ & 72 & 7 days & Pharynx & $\begin{array}{l}\mathrm{BB}, \mathrm{D}, \text { iron, } \\
\text { thyroxine, } \\
\text { antidiabetic agents, } \\
\text { terfenadine }\end{array}$ & $\begin{array}{l}\text { Myxoedema, diabetes } \\
\text { mellitus }\end{array}$ & Enalapril & NR \\
\hline 29 & $M$ & 52 & 5 days & Tongue & $\mathrm{BB}$ & Renal insufficiency & Enalapril & $5 \mathrm{mg}$ \\
\hline 30 & $\mathbf{F}$ & 51 & 2 months & Face, lips & $\begin{array}{l}\text { BB, doxycycline, } \\
\text { amitriptyline }\end{array}$ & & Lisinopril & $10 \mathrm{mg}$ \\
\hline 31 & $M$ & 59 & 3 days & NR & $\mathrm{BB}, \mathrm{D}$ & & Lisinopril & $5 \mathrm{mg}$ \\
\hline 32 & $M$ & 59 & $5-6$ months & Face & $\begin{array}{l}\text { BB, anti-epileptic } \\
\text { agents }\end{array}$ & $\begin{array}{l}\text { Diabetes mellitus } \\
\text { epilepsy }\end{array}$ & Enalapril & $20 \mathrm{mg}$ \\
\hline 33 & $M$ & 47 & 3 weeks & Lips, tongue & & & Lisinopril & $10 \mathrm{mg}$ \\
\hline 34 & $M$ & 76 & 6 days & Face, lips, tongue & $\begin{array}{r}\text { BB, Dig, } N, \\
\text { analgesics }\end{array}$ & $\begin{array}{l}\text { Angina pectoris, } \mathrm{AF}, \\
\text { prostatic } \\
\text { malignancy }\end{array}$ & Enalapril & $20 \mathrm{mg}$ \\
\hline 35 & $\mathrm{~F}$ & 61 & 1 year & Face, tongue & None & None & Lisinopril & $20-60 \mathrm{mg}$ \\
\hline 36 & $M$ & 45 & 2 months & Pharynx & Dig & $\begin{array}{c}\mathrm{AF}, \text { muscular } \\
\text { dystrophy }\end{array}$ & Enalapril & $10 \mathrm{mg}$ \\
\hline
\end{tabular}

$\mathrm{NR}=$ Not reported. $\mathrm{BB}=\beta$ blocker. $\mathrm{D}=$ Diuretic. $\mathrm{ASA}=$ Aspirin. $\mathrm{N}=$ Glyceryl trinitrate. $\beta_{2}$ stim $=\beta_{2}$ stimulating agent. Theo $=$ Theophylline. Cor $=$ Corticosteroids. Dig $=$ Digitalis. SLE $=$ Systemic lupus erythematosus. $\mathrm{MI}=$ Previous myocardial infarction. $\mathrm{AF}=\mathrm{Atrial}$ fibrillation. 
TABLE II-Appearance of angio-oedema symptoms in relation to time after start of angiotensin converting enzyme inhibitor treatment among 30 of 36 cases reported to Swedish Adverse Drug Reaction Advisory Committee, where clinical report contained exact time of onset of symptoms

\begin{tabular}{ccccccccc}
\hline & \multicolumn{7}{c}{ Weeks after start of treatment } \\
\cline { 2 - 9 } & 0 & 1 & 2 & $3-4$ & $8-9$ & $12-13$ & $52-53$ & $156-157$ \\
\hline No of cases reported & 16 & 4 & 3 & 1 & 2 & 2 & 1 & 1 \\
\hline
\end{tabular}

respective angiotensin converting enzyme inhibitor (table I). Seventeen patients (47\%) experienced their symptoms during the first week of treatment. A further six patients had angio-oedema symptoms within the next two weeks. Thus in 23 out of $30(77 \%)$ patients angio-oedema occurred within three weeks after treatment was initiated (table II). In all cases the symptoms resolved on discontinuing the drug.

One case (No 15) had non-specific skin manifestations during captopril treatment but developed angiooedema within three days after captopril was changed to enalapril. According to the filed report, the patient was later given captopril again and did not experience any symptoms of angio-oedema. However, the nonspecific skin reaction recurred but to such mild degree that the drug could be continued without any other adverse reaction.

In three patients angio-oedema occurred after over three months and after three years on angiotensin converting enzyme inhibitors. In these patients symptoms also resolved on discontinuing the drug. The reports on these patients did not disclose any other triggering factor for the angio-oedema reaction.

Two patients were being treated with aspirin. However, from the clinical records submitted to the Swedish Adverse Drug Reactions Advisory Committee it seems that these patients had been treated with antiinflammatory drugs for a long period before starting angiotensin converting enzyme inhibitors. Both developed angio-oedema within one to two weeks after initiation of angiotensin converting enzyme inhibitors.

Ten patients $(28 \%)$ were hospitalised after the abrupt onset of symptoms with a short history of
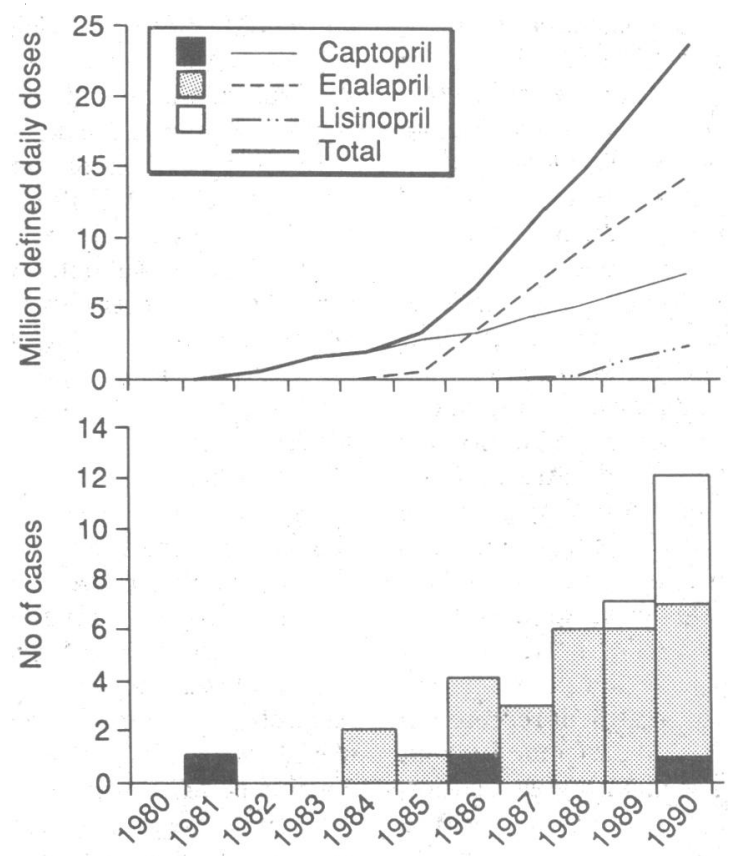

Year

FIG 1-Increase in use of angiotensin converting enzyme inhibitors captopril, enalapril, and lisinopril expressed as defined daily doses during 1981-90. Defined daily dose for captopril was initially $150 \mathrm{mg}$ but was lowered to $50 \mathrm{mg}$ in 1988 . Lower part of panel shows cases of possible angio-oedema related to use of angiotensin converting enzyme inhibitor reported to Committee on Safety of Drugs of the Swedish Medical Products Agency during each year

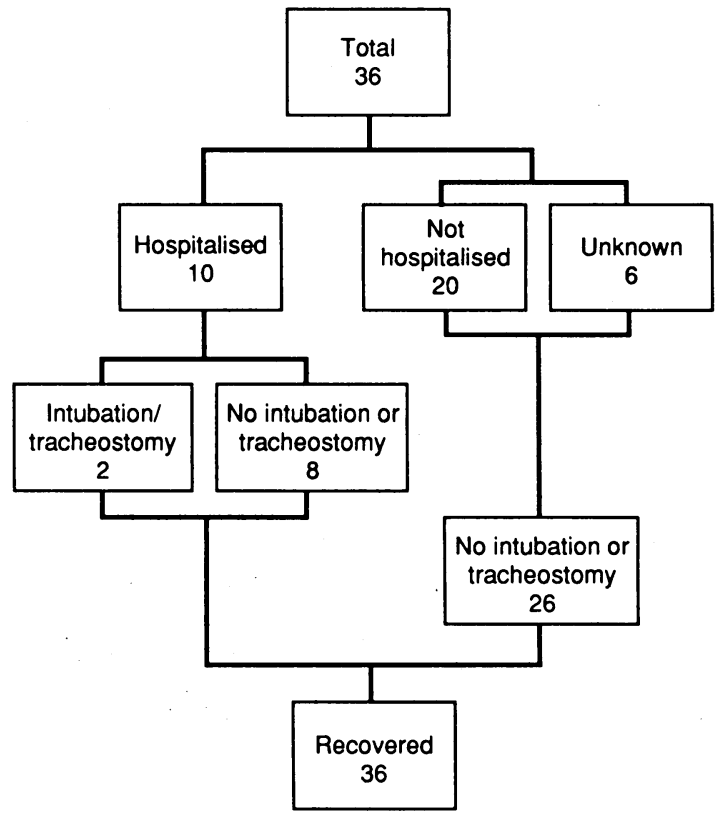

FIG 2-Outcome of 36 cases of possible angio-oedema related to use of angiotensin converting enzyme inhibitor reported to Committee on Safety of Drugs of Swedish Medical Products Agency from 1981 to end of 1990

TABLE III - Individual cases of angiotensin converting enzyme inhibitor associated angio-oedema reported to WHO's international drug information system 1980-90 (search performed 3 December 1991)

\begin{tabular}{lcc}
\hline Drug & $\begin{array}{c}\text { Total No of adverse } \\
\text { reactions }\end{array}$ & $\begin{array}{c}\text { No of reported cases of drug } \\
\text { related angio-oedema }\end{array}$ \\
\hline Captopril & 19243 & 241 \\
Enalapril & 18163 & 774 \\
Lisinopril & 6030 & 288 \\
Quinapril & 91 & 2 \\
Ramipril & 65 & 4 \\
\hline
\end{tabular}

aggravating symptoms ranging from a few hours to a few days. Figure 2 presents the outcome of all 36 cases. Two of these patients had life threatening symptoms due to laryngeal obstruction, necessitating acute intubation or tracheostomy. Altogether 26 patients (72\%) experienced oedema of the lips or tongue or further down in the pharyngeal-laryngeal region $(\mathrm{n}=$ 10) (table I). With one exception all symptoms resolved within one week after discontinuation of therapy. All patients recovered without sequelae. One patient had recurrent symptoms of oedema during one month after withdrawal of the drug.

The indication for angiotensin converting enzyme inhibitor treatment was hypertension in 32 patients and congestive heart failure in four. The occurrence of angio-oedema seemed to be unrelated to age or gender, as both men and women of a wide age span were represented in these submitted reports (see table I). Judged from the 27 patients taking enalapril there seemed to be no obvious relation between the given dose and the occurrence of symptoms - that is, angiooedema commonly occurred in the first week in patients receiving a low initial dose.

Five of the cases had ongoing treatment with corticosteroids or $\beta_{2}$ adrenergic stimulating agents for concomitant disease, and hence in these cases such treatment did not prevent the occurrence of angiooedema. Four of these patients had a diagnosis of asthma or chronic obstructive lung disease, and a fifth patient had other allergic manifestations.

Between the beginning of 1981 and December 1990 a total of 1309 individual case reports of angio-oedema judged to be related to angiotensin converting enzyme inhibitor treatment were registered with the WHO's international drug information system (table III) The annual number of reports on the three different 
Year

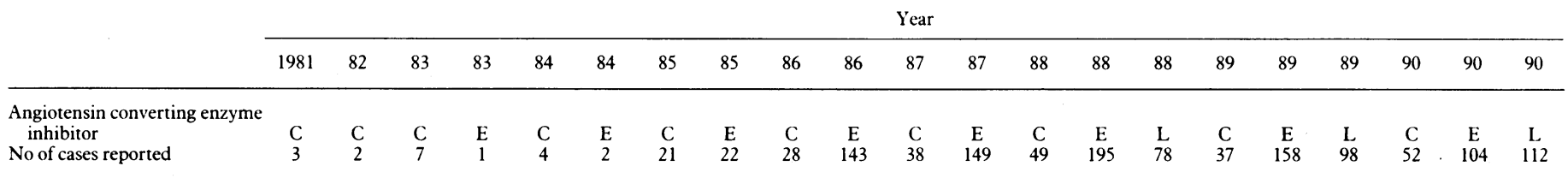

$\mathrm{C}=$ Captopril

$\mathrm{E}=$ Enalapril.

$\mathrm{L}=$ Lisinopril.

angiotensin converting enzyme inhibitors captopril, enalapril, and lisinopril are given in table IV.

\section{Discussion}

The angiotensin converting enzyme inhibitors are extensively documented antihypertensive agents which are generally well tolerated by most patients. ${ }^{13}$ They are currently regarded as first line agents in the treatment of hypertension. ${ }^{14-16}$ However, the angiotensin converting enzyme inhibitors have not been evaluated in primary preventive trials, although one such study is underway. ${ }^{17}$ Thus the risk-benefit relation of angiotensin converting enzyme inhibitor treatment in mild to moderate hypertension compared with other types of antihypertensive treatment is not known. Infrequent and potentially severe reactions to drug therapy may have a great impact on the risk-benefit relation, particularly in patients with mild to moderate hypertension, in whom the risk for future cardiovascular complications is low, at least if other risk factors are absent. ${ }^{18} 19$

The overall incidence of adverse events reported to central registers has been estimated to be around one tenth of the true rate in closely monitored clinical studies. ${ }^{8}$ In Sweden serious and dramatic adverse reactions have previously been found to be reported in $20-80 \%$ of cases once the reaction is known among the physicians seeing the cases..$^{20}$ If this is applied to the Swedish conditions during the 1980s a simple extrapolation from our data would result in a probable number of angio-oedema cases during the past 10 years in the range of 100 to 200 in the Swedish hypertensive population, which comprises around one million subjects. ${ }^{21}$ Since there is a risk of considerable underreporting of angio-oedema in relation to angio-tensin converting enzyme inhibitor treatment we think that the incidence of this potentially serious adverse reaction should be closely followed and carefully monitored.

During the five year period 1986-90 a total of 73.4 million defined daily doses of angiotensin converting enzyme inhibitors were sold in Sweden. The 32 cases reported during these years thus represent one case per 2.3 million defined daily doses, which equals one reported case per 6300 patient years. Another, and maybe more relevant, denominator (as most cases appeared early during treatment) is to use an estimate based on the number of newly started patients. Such data are available from the individual prescription register in the county of Jämtland..$^{22}$ Using enalapril as an example, the number of patients who received their first prescription during 1989 can be extrapolated from the Jämtland study to be about 13400 in the whole of Sweden. The six reported to have developed angiooedema during the first weeks of treatment represent a reported frequency of about $1 / 2200$ patients. Such an estimate must, however, be viewed with great caution as the actual reporting rate is unknown and the estimate of the denominator is rough. The estimate may, however, give an indication of the order of magnitude of these problems.

Previous reports of angio-oedema cases indicate that up to $20 \%$ may be potentially life threatening. ${ }^{8}$ The review by Slater $e t$ al described four deaths, in at least one of which-and possibly two-angio-oedema was considered as the most probable cause. ${ }^{8}$ In the other cases, where life threatening symptoms were promptly treated with adrenaline, there was a favourable outcome. This therapy was also effective in the reported severe cases in Sweden.

\section{TIMING OF ONSET OF ANGIO-OEDEMA}

In agreement with a previous report ${ }^{8}$ we found that the incidence of angiotensin converting enzyme inhibitor related angio-oedema was highest during the first weeks of treatment. Thereafter the incidence decreased sharply, and only isolated cases were reported during continued treatment. However, we emphasise that angio-oedema may develop even after long periods of previously uneventful angiotensin converting enzyme inhibitor treatment in rare individual cases. ${ }^{23}$ The reporting of angio-oedema during angiotensin converting enzyme inhibitor treatment may be related to three different phenomena-namely, (a) a specific angiotensin converting enzyme inhibitor induced angio-oedema reaction occurring in predisposed individuals in relation to the first few doses; $(b)$ sporadic angio-oedema essentially due to other factors with no pathogenic or temporal relation to the administration of the angiotensin converting enzyme inhibitor; or $(c)$ that during angiotensin converting enzyme inhibition other factors may more easily trigger this specific reaction. The prompt recovery after withdrawal of the angiotensin converting enzyme inhibitor supports the conclusion that the inhibitor was either the precipitating factor or a prerequisite for the triggering of such an event.

Most of the reported Swedish cases were mild and resolved on stopping treatment, but, as stated above, potentially life threatening cases were also encountered and could occur in association with the first doses of angiotensin converting enzyme inhibitor. Patients at particularly increased risk for severe angio-oedema requiring prompt medical intervention may be those with a history of idiopathic angio-oedema, as suggested by Orfan et al. ${ }^{24}$ Unfortunately, the reports of the Swedish cases do not include this type of information with which to validate the suggestion. However, a careful patient interview with respect to such previous symptoms may be of great importance to avoid prescribing an angiotensin converting enzyme inhibitor to such patients at risk for this specific adverse reaction.

Review of the Swedish case reports does not reveal any specific predisposing factors for developing angiooedema in association with angiotensin converting enzyme inhibitor therapy. It can occur in patients already receiving antiallergic medication for other medical reasons. However, it is interesting that one out of six of our reported cases also had obstructive respiratory disease. This is a higher prevalence than would be expected from observations in the hypertensive as well as in the normotensive population. ${ }^{25}$ This may have many explanations. It may be that angio-oedema in association with angiotensin converting enzyme inhibitor therapy occurs with a higher incidence in these patients. However, it may also be due to an increased use of angiotensin converting enzyme inhibitors in these patients, in whom $\beta$ blocking agents are considered contraindicated. Thirdly, this type of adverse reaction may be given more attention and consequently reported more readily 
in subjects with a previously known respiratory disorder.

\section{POTENCY OF AGENTS TO INDUCE REACTION}

An important issue is whether angiotensin converting enzyme inhibitors differ in their potency to induce the reaction. It is evident from the Swedish experience and from reports to the WHO's international drug information system that angio-oedema may occur in relation to at least five different types of angiotensin converting enzyme inhibitor. Although enalapril predominates in both Swedish records and international files, spontaneous reporting cannot be used adequately to compare the incidences of adverse effects with different drugs. Valid comparisons can be performed only in carefully designed controlled prospective studies with an adequate sample size in relation to the event in focus. However, it is still of interest that recent reports indicate that there may be intolerance to one angiotensin converting enzyme inhibitor, which does not preclude the successful use of another agent of the same class, and that the successful changing from one agent to another may indicate that there are differences in the propensity for a particular type of adverse reaction. ${ }^{826}$

Interestingly, a few patients with angio-oedema taking enalapril were reported not to develop new symptoms after switching to captopril. ${ }^{8}$ On the other hand, it has also been reported that patients with angiooedema associated with taking captopril may not have it after changing to enalapril..$^{26}$ To our knowledge only one of the Swedish patients was challenged with another type of angiotensin converting enzyme inhibitor after recovering from his symptoms. This particular patient developed angio-oedema when taking enalapril but not with captopril. The reason for this discrepancy in reactivity between treatments is not known. One possible explanation for these observations may be individual adjustment of dosing as well as of concomitant therapy after switching to the alternative angiotensin converting enzyme inhibitor. However, although a beneficial effect after a change of angiotensin converting enzyme inhibitor may occur, it is not generally advisable to cross over to another agent within the same class once angio-oedema symptoms have occurred in the individual patient. ${ }^{26}$

The number of cases reported to the WHO's international drug information system were few during the early 1980s but increased substantially during the second half of the decade. There are at least two probable explanations. The usage of angiotensin converting enzyme inhibitors worldwide increased during the late 1980s and doctors could have become more aware of this specific adverse drug reaction and possibly also more eager and willing to report such an uncommon adverse effect.

\section{MECHANISM OF ADVERSE EFFECT}

The exact mechanism of angio-oedema after angiotensin converting enzyme inhibition is not known Present data suggest that the underlying cause is biochemical rather than immunological. ${ }^{23}$ It is tempting to speculate that one possible mechanism may be related to interaction with the kinin-kallikrein systems in genetically or environmentally predisposed individuals. Inhibition of kinin degradation by angiotensin converting enzyme inhibitors may amplify various kinin mediated local reactions $\mathrm{s}^{27} 28$ and thereby induce oedema. Activation of the kallikrein-kinin system has also been suggested in the rare hereditary form of angio-oedema, since these patients often show a deficiency in the inhibitor of the first complement, which acts as an inactivator of kallikrein. ${ }^{428}$ However, in several cases $^{8}$ the concentrations of the first complement have been normal, indicating that the mechanisms behind the oedema formation in the angiotensin converting enzyme inhibitor precipitated cases of angio-oedema differ from those in the rare hereditary form of the disease. Although no evidence exists, one may also speculate that patients with relative deficiencies in important enzymes for bradykinin degradation may be at greater risk of developing angiooedema-like reactions on angiotensin converting enzyme inhibitor therapy. ${ }^{29}$

\section{CONCLUSION}

In summary, angio-oedema in relation to angiotensin converting enzyme inhibitor treatment is a rare but potentially life threatening reaction which in most instances occurs shortly after the start of treatment. It can be expected that the numbers of patients who experience such reactions will increase, given the growing numbers who are being treated with these drugs. In order to evaluate the true incidence of this adverse reaction it is of great importance that suspected future cases will be carefully investigated and reported to the national drug monitoring centres. If angiotensin converting enzyme inhibitor induced angio-oedema is suspected the treatment should promptly be interrupted and replaced by an agent belonging to another class of drugs. At present it cannot generally be recommended to change from one angiotensin converting enzyme inhibitor to another. In cases where symptoms are from the tongue, pharynx, or larynx an immediate subcutaneous adrenaline administration is of vital importance and the patient should be observed and hospitalised for at least 12 to 24 hours.

Professor Ralph Edwards at the WHO Collaborating Centre for International Drug Monitoring in Uppsala, Sweden, provided valuable information about the international drug information system register.

1 Quincke H. Über akutes umscreibenes Hautödem. Monatschrift für Praktischer Dermatologie 1882;1:129.

2 Landeman NS. Hereditary angioneurotic oedema. F Allergy 1962;33:316-29. 3 Osler W. Hereditary angioneurotic oedema. Am f Med Sci 1888;95:362.

4 Soter NA, Austen KF. Urticaria, angioedema and mediator release in human in response to physical environmental stimuli. Fed Proc 1977;36:1736-41.

5 Kaplan AP. Drug induced skin disease. F Allergy Clin Immunol 1984;73:573 97.

6 Rush JE, Merrill DD. The safety and tolerability of lisinopril in clinical trials f Cardiovasc Pharmacol 1987;9 (suppl 3):99-107.

7 Wood SM, Mann RD, Rawlins MD. Angioedema and urticaria associated with angiotensin converting enzyme inhibitors. BMf 1987;294:91-2.

8 Slater EE, Merrill DD, Guess HA, Roylance PJ, Cooper WD, Inman WHW, et al. Clinical profile of angioedema associated with angiotensin convertingenzyme inhibition. FAMA 1988:260:967-70

9 Wernze H. Angioneurotisches Ödem unter ACE-Hemmern: Häuftigkeit, klinische Charakteristik, Auslösemeschanismen. Z Kardiol 1988;77 (suppl 3):61-4.

10 Warner NJ, Rush JE. Safety profile of the angiotensin-converting enzyme inhibitors. Drugs 1988;35(suppl 5):89-97.

11 Swedish Drug Information System (SWEDIS). The adverse reaction register of the Swedish Medical Products Agency. Uppsala: SWEDIS Developmen Centre. (Continuously updated computer register.)

12 Olsson S. International reporting of adverse drug reactions: the WHO program. Semin Dermatol 1989;8:72-4.

13 Frohlich E. Angiotensin converting enzyme inhibitors. Hypertension 1989;13 (suppl I):I-125-30.

141989 Guidelines for the management of mild hypertension: a memorandum from a WHO/ISH meeting. $\mathcal{F}$ Hypertens 1989;7:689-93.

15. Joint National Committee on Detection, Evaluation, and Treatment of High Blood Pressure. Report. Arch Intern Med 1988;148:1023-38.

16 Rekommendationer från ett expertmöte: individualiserad hypertonibehandling. Lakartidningen 1990;87:2255-8.

17 The CAPPP Group. The captopril primary preventive project: a prospective intervention trial of angiotensin converting enzyme inhibition in the
ing treatment of hypertension. F Hypertens 1990;8:985-90.

18 Medical Research Council Working Party. MRC trial of treatment of mild hypertension: principal results. BMF 1985;291:97-104.

19 Samuelsson O, Wilhelmsen L, Elmfeldt D, Pennert K, Wedel H, Wikstrand $\mathrm{J}$, et al. Predictors of cardiovascular morbidity in treated hypertension results from the primary preventive trial in Göteborg, Sweden. $\mathcal{F}$ Hyperten $1985 ; 3: 167-76$

20 Wiholm BE. Spontaneous reporting of ADR. Fertilization with register data on morbidity and drug utilization. In: Skandia international symposia. Deterction and prevention of adverse drug reactions. October 18-20, 1983. Stockholm: Almqvist and Wiksell International, 1984:152-67.

21 Råstam L, Berglund G, Isacsson S-O, Rydén L. The Skaraborg hypertension project. I. The prevalence of hypertension. Acta Med Scand 1986;219:243-8.

22 Wessling A, Boëthius G, Sjöqvist F. Prescription monitoring of drug dosages in the county of Jämtland and Sweden as a whole in 1976, 1982 and 1985. Eur f Clin Pharmacol 1990;38:329-34.

23 Chin HL, Buchan DA. Severe angioedema after long-term use of an angiotensin-converting enzyme inhibition. Ann Intern Med 1990;112:312-3. 
24 Orfan N, Patterson R, Dykewicz MS. Severe angioedema related to ACEinhibitors in patients with a history of idiopathic angioedema. $\mathcal{F A M A}$ 1990;264:1287-9.

25 Sears M. Epidemiological trends in bronchial asthma. In: Kaliner MA, Barnes PJ, Persson CG, eds. Asthma. Its pathology and treatment. New York: Marce Dekker Inc, 1991:1-41.

26 Rucinska EJ, Small R, Mulcahy WS, Snyder DL, Rodel PV, Rush JE, et al. Tolerability of long-term therapy with enalapril maleate in patients resistan to other therapies and intolerant to captopril. Medical Toxicology and Adverse Drug Experiments 1989;4:144-52.
27 Schrör K. Converting enzyme inhibitors and the interaction between kinins and eicosanoids. F Cardiovasc Pharmacol 1990;15 (suppl 6): $\mathrm{S60}-8$.

28 Donaldson VH, Evans RR. A biochemical abnormality in hereditary angioneurotic oedema: absence of serum inhibitor of $\mathrm{Cl}$-esterase. Am $\mathcal{J} \mathrm{Med}$ 1963;35:37-44.

29 Erdös EG. Some old and some new ideas on kinin metabolism. $\mathcal{F}$ Cardiovasc Pharmacol 1990;15 (suppl 6):S20-4

\title{
Randomised controlled trial of atenolol and pindolol in human pregnancy: effects on fetal haemodynamics
}

\author{
Sven Montan, Ingemar Ingemarsson, Karel Maršál, Nils-Otto Sjöberg
}

\section{Abstract}

Objective-To compare the effects of uteroplacental circulation of two $\beta$ adrenoceptor blockers, atenolol (cardioselective) and pindolol (non-selective with intrinsic sympathomimetic activity).

Design-Controlled double blind double dummy study.

Setting-Departments of obstetrics and gynaecology in two Swedish university hospitals.

Subjects-29 women with pregnancy induced hypertension in the third trimester, 13 randomised to atenolol and 16 to pindolol.

Main outcome measures-Pulsatility index in fetal aorta, umbilical artery, and maternal arcuate artery. Volumetric blood flow in fetal aorta and umbilical vein.

Results - Mean arterial blood pressure decreased by $9.0(95 \%$ confidence interval -13.0 to $-5.0) \mathrm{mm} \mathrm{Hg}$ in the atenolol group and by 7.8 $(-11.4$ to -4.2$) \mathrm{mm} \mathrm{Hg}$ in the pindolol group. During atenolol treatment the pulsatility index increased significantly from 1.82 (SD 0.20 ) to 2.07 $(0.32)$ in the fetal thoracic descending aorta, from $1.44(0.28)$ to $1.79(0.27)$ in the abdominal aorta, and from $0.93(0.17)$ to $1.05(0.19)$ in the umbilical artery; the volumetric blood flow in the umbilical vein decreased from $106(28.8)$ to $84(22.6) \mathrm{ml} / \mathrm{min} / \mathrm{kg}$. No such changes were seen after treatment with pindolol. Birth weight was similar in the two groups but placental weight was significantly different $(529$ (122) $\mathrm{g}$ in atenolol group $v 653(136) \mathrm{g}$ in pindolol group; $\mathbf{p}=\mathbf{0} \cdot 03$ ).

Conclusion-The hypotensive effect was similar with both drugs, but only the $\beta_{1}$ blocker atenolol had significant effects on fetal haemodynamics, although within normal ranges. The implications of these findings can be only speculative, but negative fetal consequences of $\beta_{1}$ adrenoceptor blockade cannot be excluded.

and Gynaecology

University Hospital,

S-22185 Lund, Sweden

Sven Montan, senior lecturer

Ingemar Ingemarsson,

associate professor

Nils-Otto Sjöberg, professor

Department of Obstetrics and Gynaecology, Malmö

University Hospital,

Malmö, Sweden

Karel Maršál, associate professor

Correspondence and requests for reprints to: Dr Montan. asphyxia. ${ }^{45}$ Furthermore, in pregnant women with hypertension in the third trimester, atenolol increased fetal and uteroplacental peripheral vascular resistance. ${ }^{6}$

A few studies on $\beta$ blockers with intrinsic sympatho- mimetic activity, such as pindolol, ${ }^{7}$ and with $\alpha_{1}$ blocking activity, such as labetalol, ${ }^{8}$ using a gammacamera have suggested that they produce little change of uteroplacental blood flow. We compared two $\beta$ blockers with different actions, atenolol and pindolol. We studied maternal as well as fetal haemodynamics in women with pregnancy induced hypertension by using Doppler ultrasonography.

\section{Patients and methods}

The study included 32 women who were normotensive in the first trimester and who were admitted to our hospitals with pregnancy induced hypertension (blood pressure $140 / 90 \mathrm{~mm} \mathrm{Hg}$ or more on two occasions four hours or more apart). Women who had sustained hypertension after three days' rest in hospital, who met none of the exclusion criteria, and who agreed to participate in the study after being given oral and written information were included. The mean gestational age at admission was 35 (range 33-38) completed weeks. Exclusion criteria were multiple gestation, diastolic blood pressure $110 \mathrm{~mm} \mathrm{Hg}$ or more, estimated fetal weight deviation of more than $-22 \%$ ( 2 SD from estimated mean weight for gestational age), gestational age at recruitment less than 32 weeks, other drug treatment, contraindications to prolonging the pregnancy, or giving $\beta$ blockers. The women were randomly allocated to antihypertensive treatment with either atenolol or pindolol. A double blind double dummy technique was used to allocate the antihypertensive drugs. Information on which treatment the women were given was stored in sealed envelopes and these were not opened until the study was completed. Two patients in the atenolol group had only one blood flow velocity measurement and were excluded; one was delivered within one week and the other rejected further participation in the study. One patient in the pindolol group was excluded because of side effects (tachycardia). Thus 29 patients participated in the study: 13 in the atenolol group and 16 in the pindolol group.

All pregnancies were dated by ultrasound measurement of the fetal biparietal diameter in the first half of gestation. Before women were entered into the study, fetal weight was estimated from the biparietal diameter and the mean abdominal diameter. ${ }^{9}$ None of the fetuses was small for gestational age-that is, with weigh more than 2 SD below the mean. Seven women had proteinuria (three in the atenolol group and four in the pindolol group).

Bedrest and limited activity was advised during the first three days in hospital. Blood pressure was measured four times daily with the patient in a semirecumbent position by a mercury sphygmomanometer with appropriate cuff. Korotkoff phase 5 was used as an indicator of diastolic blood pressure. Mean 